\title{
Studi Perilaku Teritorial Burung Cangak Abu (Ardea cinerea Linn.) di Kebun Raya dan Kebun Binatang Gembiraloka Yogyakarta
}

\section{Study of Cangak Abu (Ardea cinerea Linn) Territorial Behaviour at Gembira Loka Botanical Garden and Zoo Yogyakarta}

\author{
Wahyu Nugroho ${ }^{1}$, Djuwantoko ${ }^{2 *}$, Wibowo N. Jati ${ }^{1}$
}

1. Fakultas Biologi Universitas Atma Jaya Yogyakarta. Jl. Babarsari No 44. Yogyakarta 55281

2. Fakultas Kehutanan, Universitas Gadjah Mada Yogyakarta. Bulaksumur, Yogyakarta 55281 E-mail: juwantoko@yahoo.com*Penulis untuk korespondensi

\begin{abstract}
This study aim to see on ecological aspect of Cangak Abu specifically on its behavior in defending their terittory. This research was done from July to August 2004. Data collecting was done using territory mapping methods with three observation area $\left(1 s^{t}-3 r^{d}\right)$. One pair of Cangak Abu observed at each area. Cangak Abu showed some behavior such as vocalization, sound, visual display, visual display-sound, visual display-sound-shortflight, patroling flight and fighting. The territories on frist to third observation areas were $O A: 9 \mathrm{~m}^{2} ; \mathrm{OA}: 6 \mathrm{~m}^{2}$ and $O A: 9 \mathrm{~m}^{2}$ respectively.
\end{abstract}

Key words : Cangak Abu, territory

Diterima : 29 Juni 2005, disetujui : 28 Juli 2005

\section{Pendahuluan}

Indonesia memiliki keanekaragaman satwa yang cukup tinggi. Khusus untuk jenis satwa burung, Indonesia memiliki 1539 jenis burung yang tersebar dari Sabang sampai Merauke (Shannaz et al., 1995). Dari jumlah itu, 381 jenis di antaranya adalah jenis endemik. Di antara jenis endemik tersebut, tersebar beraneka ragam familia eksotis yang semuanya termasuk dalam kriteria dilindungi, bahkan ada yang masuk dalam status terancam punah. Di antara jenis satuan burung yang dilindungi itu adalah jenis burung paruh bengkok, burung kicauan dan jenis lainnya, termasuk diantaranya jenis burung air.

Cangak Abu (Ardea cinerea Linn.) memiliki ciri khas yaitu hidupnya yang soliter namun berkelompok (Widati, 2000). Soliter pada saat mencari makan, sedangkan berkelompok pada saat bersarang, kawin dan berkembang biak. Dalam hidup berkoloni, Cangak Abu memiliki beberapa perilaku khas yang berkaitan dengan perannya di dalam koloni. Beberapa perilaku seperti membuat sarang, kawin, berkembang biak, mempertahankan teritori dan lainnya adalah obyek kajian yang sangat perlu untuk diteliti secara lebih dalam. Kajian ini sangat berguna sebagai sumber data dalam upaya konservasi spesies ini secara menyeluruh.

\section{Metode Penelitian}

\section{Lokasi dan Waktu Penelitian}

Penelitian dilakukan di Kebun Raya dan Kebun Binatang Gembira Loka Yogyakarta. Pengambilan data dilakukan selama bulan Juli sampai Agustus 2004.

Pengamatan dilakukan pada pagi hari antara pukul 06.30 sampai 09.00 berturut-turut selama lima hari secara serentak dari tiap lokasi. Waktu ini dipilih karena aktivitas teritorial burung umumnya aktif pada pagi hari (Bibby et al., 1992). 
Alat dan Bahan

Alat dan bahan yang digunakan Binokuler untuk mengamati perilaku teritori burung, kamera foto dan kamera video digunakan untuk merekam perilaku teritori, buku panduan pengenalan burung digunakan untuk identifikasi jenis lain yang berinteraksi dengan Cangak Abu, alat tulis digunakan untuk mencatat tiap perilaku, stop watch digunakan untuk mencatat waktu perilaku teritori.

\section{Pengambilan Data}

Metode pengamatan teritori Cangak Abu dilakukan dengan Territory Mapping Methods (Bibby et al., 1992), cara kerjanya adalah: (1) Membuat blok-blok pengamatan teritori. Hasil dari pengamatan awal akan digunakan untuk pembuatan blok-blok pengamatan dengan luasan yang lebih kecil, sehingga mempermudah pengamatan dan pemetaan teritori burung. (2) Pada tiap-tiap kelompok dilakukan pengamatan dan pemetaan teritori selama lima hari berturut-turut. (3) Pengamatan dan pemetaan teritori setiap hari dicatat dan dipetakan pada lembar peta pengamatan harian. Pada setiap lembar peta pengamatan tersebut ditandai dengan kode pengamatan harian (visit code) dengan huruf $\mathrm{A}, \mathrm{B}, \mathrm{C}, \mathrm{D}$, dan $\mathrm{E}$.

Aktivitas-aktivitas penandaan teritori yang diamati meliputi pengusiran, patrolling flight, vokalisasi (calling) yang menunjukkan penandaan teritori (suara ribut) ataupun vokalisasi komunikasi serta aktivitas-aktivitas lainnya yang menunjukkan aktivitas teritorial (Bibby et al., 1992). Untuk mempermudah pencatatan hasil pengamatan pada peta digunakan simbol-simbol aktivitas teritori seperti pada Tabel 1.

Tabel 1. Simbol-simbol aktivitas teritorial Cangak Abu

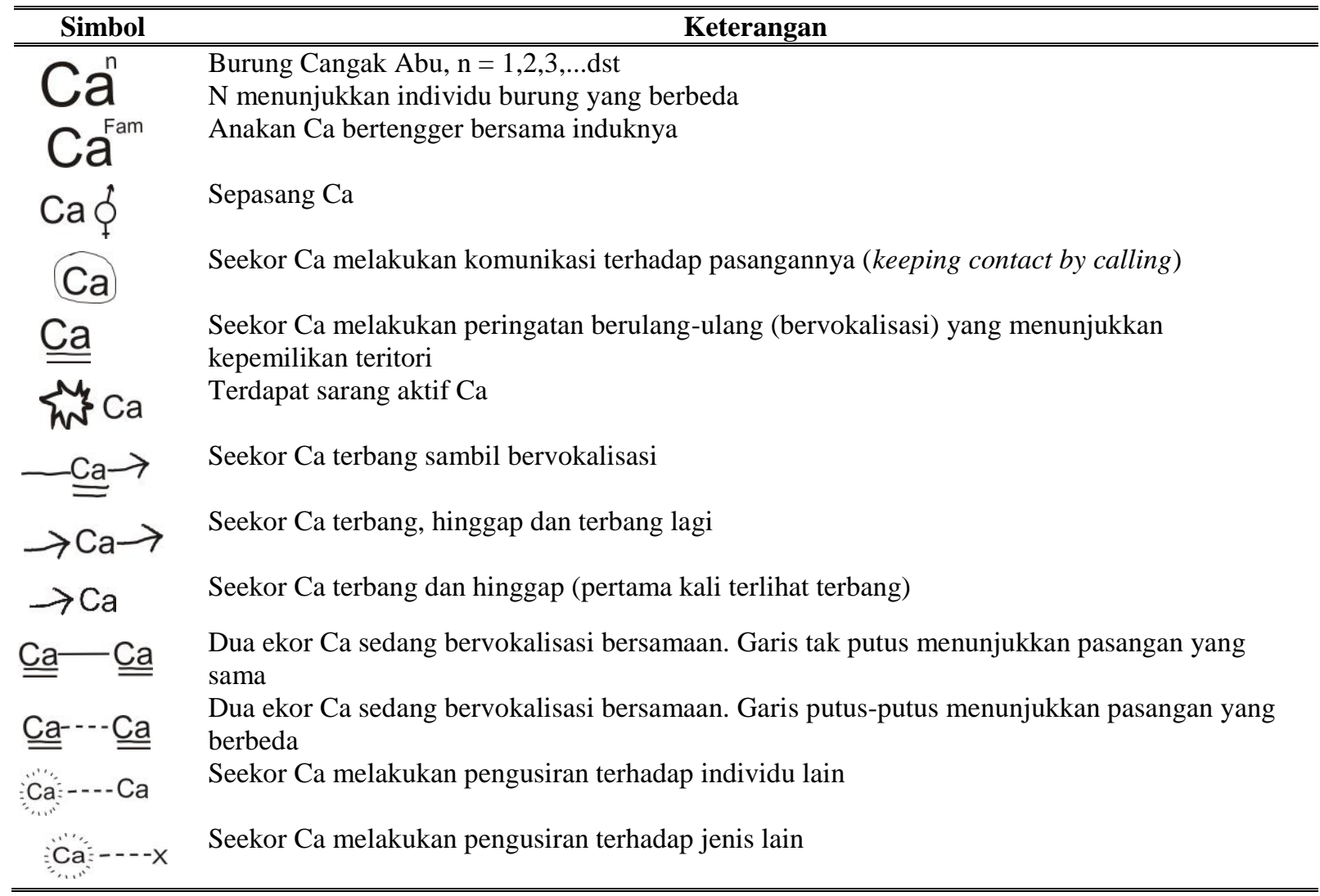

(Sumber : Bibby et al., 1992) 


\section{Hasil dan Pembahasan}

\section{Aktivitas Teritorial Cangak Abu di lokasi I}

Aktivitas teritorial Cangak Abu di lokasi I yaitu pohon Asem (Tamarindus indicus) teramati sejak hari ke-1 sampai hari ke-5 (hari ke-1 dilambangkan dengan simbol A, hari ke-2 dengan simbol B, dan seterusnya sampai hari ke-5). Perlu diketahui bahwa pohon Asem ini letaknya berdekatan dengan pohon lainnya seperti pohon Bodhi (Ficus religiosa), pohon
Beringin (Ficus benjamina) dan Rasamala (Altingia excelsa). Karena letaknya berdekatan ini, maka tidak jarang banyak terjadi beberapa kali perilaku teritori setiap menitnya. Bentuk perilaku teritori yang terjadi pada lokasi I banyak didominasi oleh perilaku pengusiran, baik dengan suara, visual display, visual display disertai suara dan dengan kontak fisik seperti berkelahi.

Untuk melihat perilaku teritorial yang terjadi pada lokasi I, lihat Tabel 2.

Tabel 2. Beberapa simbol aktivitas teritorial Cangak Abu di lokasi I

\begin{tabular}{ll}
\multicolumn{1}{c}{ Simbol } & Keterangan \\
& Cangak Abu mengusir individu lain dengan bulu jambul dan bulu dada yang berdiri namun \\
&
\end{tabular}

Beberapa bentuk perilaku teritorial adalah visual display, ditandai dengan bulu jambul dan dada yang berdiri namun tanpa suara (terjadi pada hari ke-1 dan hari ke-2), visual display dengan diikuti suara (terjadi pada hari ke-1, hari ke-3, hari ke-4, dan hari ke-5), visual display, suara diikuti terbang pendek (terjadi pada hari ke-2 dan hari ke-4), pengusiran dengan cara berkelahi (fighting), ditunjukkan dengan perilaku saling menjulurkan leher dan mencakar antara Cangak Abu satu dan individu lainnya (terjadi pada hari ke-5).

\section{Aktivitas Teritorial Cangak Abu di Lokasi II}

Berbeda dengan lokasi I, lokasi II terdiri dari kumpulan pohon pinus yang tumbuh secara homogen pada jarak yang teratur serta jauh dari pohon lainnya di lokasi I. Satu172 satunya pohon yang dekat dengan lokasi II adalah pohon Beringin, sehingga ada perilaku pengusiran terhadap jenis lain, yaitu kowak malam yang memang banyak bersarang pada pohon beringin tersebut. Akibat letaknya yang jauh tersebut, maka perilaku teritori yang terjadi di lokasi II tidak sering terjadi seperti halnya di lokasi I. Visualisasi perilaku di lokasi II dari hari ke-1 sampai ke-5 dapat dilihat pada Tabel 3.

Beberapa bentuk perilaku teritorial adalah vokalisasi (terjadi pada hari ke-1, dilakukan oleh baik jantan maupun kedua pasangan), visual display (terjadi pada hari ke5 terutama pada saat Cangak Abu mengusir Kowak Malam dan Kuntul Kerbau, visual display dengan suara lantang (ini terjadi pada hari ke-2) sampai akhirnya pengusiran dengan terbang pendek (terjadi pada hari ke-2, dan hari ke-5). 
Tabel 3. Beberapa aktivitas teritorial Cangak Abu di lokasi II

\begin{tabular}{ll}
\hline \multicolumn{1}{c}{ Simbol } & \multicolumn{1}{c}{ Keterangan } \\
\hline & Cangak Abu bervokalisasi secara berulang-ulang \\
& Cangak Abu mengusir individu lain dengan bulu jambul dan dada berdiri, diikuti suara parau \\
& kraaak \\
& Cangak Abu mengusir individu lain; bulu jambul dan dada berdiri, diikuti suara parau dan \\
& terbang pendek \\
\end{tabular}

\section{Aktivitas Teritorial Cangak Abu di Lokasi III}

Pada lokasi III perilaku vokalisasi paling banyak terjadi, karena tipikal pohon Rasamala banyak dijadikan lokasi sarang, ini tanda daerah teritorial masing-masing pasangan (Tabel 4).

Sebagian besar perilaku teritori didominasi oleh perilaku vokalisasi. Vokaliasi dibedakan menjadi dua jenis, yaitu vokalisasi pertama dengan pasangan lain (terjadi pada hari ke-1, 2, 3, 4 dan 5). Kedua yaitu vokalisasi yang dilakukan terhadap pasangannya (hanya terjadi pada hari ke-1). Perilaku vokalisasi ini meningkat menjadi bentuk visual display (teramati pada hari ke-5), visual display disertai suara (pada hari ke-5) serta visual display, suara diikuti dengan terbang (hanya terjadi pada hari ke-1), kemudian perilaku yang nampak selanjutnya yaitu terbang mengelilingi sarang sambil bersuara (patrolling flight).

Tabel 4. Beberapa aktivitas teritorial Cangak Abu di lokasi III

\begin{tabular}{ll}
\hline & Cangak Abu bervokalisasi secara berulang-ulang terhadap Cangak Abu lain yang bukan \\
pasangannya
\end{tabular}

\section{Teritori Cangak Abu dalam Koloni}

Cangak Abu, seperti halnya jenis burung lainnya, akan bersifat teritorial pada saat tertentu. Ehrlich et al., (1989) mengklasifikasikan teritori ke dalam beberapa tipe berdasarkan atas sumber daya yang dilindungi oleh spesies tersebut. Tipe A yaitu teritori untuk kawin, bersarang dan makan, Tipe B yaitu teritori untuk kawin dan bersarang, tipe $\mathrm{C}$ yaitu teritori bersarang, tipe D yaitu teritori untuk mencari pasangan dan kawin, tipe E teritori untuk beristirahat dan tipe 
F yaitu teritori untuk musim dingin (mencakup daerah makan dan beristirahat).

Berdasarkan hasil pengamatan dapat diketahui bahwa Cangak Abu merupakan jenis burung air yang teritorial saat berada di dalam koloni. Di dalam daerah teritorinya, Cangak Abu melakukan berbagai aktivitas, mulai dari pembuatan sarang sampai bersarang. Cangak Abu dalam koloni mempertahankan teritorinya untuk bersarang termasuk tipe $\mathrm{C}$, yaitu teritori yang dipertahankan untuk bersarang (nesting teritory).

Cangak Abu melakukan aktivitas teritorinya di tempat terbuka, seperti di ujung tajuk, dan dahan-dahan terbuka dengan daundaun yang jarang. Berdasarkan pengamatan terhadap tinggi pohon dan letak sarang, nampak bahwa Cangak Abu lebih cenderung memilih pohon dengan ketinggian yang cukup. Menurut Widati (2000) tinggi rata-rata 30,4 \pm $5,17 \mathrm{~m}$ dan letak sarang pada pohon rata-rata adalah $26,3 \pm 3,96 \mathrm{~m}$ di atas permukaan tanah. Selain pohon yang tinggi, kanopi yang rapat dan rimbun adalah syarat yang cocok untuk lokasi sarang.

Aktivitas teritorial Cangak Abu sangat dipengaruhi oleh keadaan cuaca dan intensitas sinar matahari. Pengaruh cuaca dapat dibuktikan dengan minimnya aktivitas teritori termasuk juga aktivitas harian yang teramati pada saat cuaca mendung, dari pengamatan hari ke-3. Pada awal jam pengamatan (jam 6.00 - jam 7.30) cuaca mendung, hampir tidak ditemui aktivitas teritorial maupun nonteritorial. Semua nampak bertengger di sarangnya. Baru setelah sinar matahari mulai nampak dan intensitas sinar yang menghangatkan suhu udara baru teramati beberapa pergerakan seperti terbang dan suara yang berisik pada koloni di tiap lokasi, termasuk di dalamnya beberapa perilaku teritori.

\section{Perilaku Teritori Cangak Abu}

Bentuk aktivitas teritori Cangak Abu ditunjukkan dengan beberapa visualisasi seperti suara, visual display, patrolling flight dan berkelahi (fight/combat). Berdasarkan dari macam bentuk perilaku tersebut, maka bentuk perilaku teritori Cangak $\mathrm{Abu}$ dapat dikategorikan ke dalam dua bentuk perilaku :

\section{Perilaku peringatan}

Bentuk perilaku peringatan ditandai dengan vokalisasi dan patroling flight. Vokalisasi adalah bentuk perilaku bersuara yang dilakukan oleh Cangak Abu. Vokalisasi sering ditandai dengan suara Krak krak krak krak pendek dan berulang. Tujuan vokalisasi untuk menandai daerah teritori individu yang bersangkutan atau sebagai tanda peringatan saat ada intruder yang masuk daerah teritorinya. Patroling flight adalah perilaku terbang mengelilingi sarang sambil bersuara. Tujuan dari patrolling flight ialah sebagai tanda kepada individu lain dari satu pohon tentang daerah teritorinya, patrolling flight ini juga berfungsi sebagai tanda kepada individu lain agar tidak masuk lagi ke dalam daerah teritorinya. Patrolling flight sering ditandai dengan suara Krak krak krak krak pendek dan berulang.

\section{Perilaku pengusiran}

Bentuk perilaku peringatan ditandai dengan perilaku visual display dan berkelahi (fighting). Visual display adalah upaya pengusiran terhadap kehadiran individu lain yang bukan pasangannya. Biasanya bentuk visual display dilakukan dengan cara jambul berdiri diikuti dengan bulu dada yang berdiri serta leher yang ditegakkan ke atas dan disertai dengan suara. Dari hasil pengamatan ada beberapa variasi suara yang terdengar saat Cangak Abu melakukan visual display, yaitu bunyi Kraaaaak rendah dan panjang, kraaak rendah pendek, kraaaaak tinggi dan kraaaaak tinggi berulang. Selain dengan suara, visual display juga sering diikuti dengan terbang pendek (atau lebih tepatnya melompat) jarak lompatan berkisar $3 \mathrm{~m}$ dari sarang.

Bentuk pengusiran dengan cara berkelahi umumnya jarang terjadi. Biasanya dengan bersuara saja, intruder sudah pergi. Namun kadang ada intruder yang resisten dengan beberapa perilaku pengusiran tersebut, sehingga Cangak Abu melakukan upaya berkelahi dengan intruder dalam upaya mempertahankan teritorinya. Berkelahi ditandai dengan bentuk saling mematuk dan mencakar antara Cangak Abu dengan intrudernya. Perilaku berkelahi sering diikuti 
dengan suara kraaaaak panjang dan berulang adalah suara yang sering terdengar saat perilaku berkelahi berlangsung.

Selain terhadap individu yang sama, Cangak Abu juga sering melakukan pengusiran terhadap jenis yang berbeda. Dari hasil pengamatan diamati bahwa jenis Kowak Malam Abu (Nycticorax nycticorax) dan Kuntul Kerbau (Bulbucus ibis) adalah jenis lain yang memasuki teritori burung Cangak Abu. Jenis Kowak Malam Abu adalah jenis yang menempati koloni yang sama dengan burung Cangak Abu. Koloni Kowak Malam Abu ini terdapat di sisi selatan pada strata pertama tajuk pada pohon beringin, sehingga tidak jarak mereka juga terkadang menempati teritori Cangak Abu hanya sekedar untuk bertengger atau mencari ranting sarang.

\section{Luas Teritori Cangak Abu}

Banyaknya jumlah sarang dalam satu pohon tersebut yang menyebabkan luas teritori Cangak Abu di dalam pohon Asem menjadi terbatas. Hasil pengukuran luas teritori menunjukkan luas teritori pasangan Cangak Abu di Lokasi I adalah $9 \mathrm{~m}^{2}$, lokasi II $6 \mathrm{~m}^{2}$ dan lokasi III adalah $9 \mathrm{~m}^{2}$.

Berdasarkan pengamatan terhadap kanopi pohon, diketahui bahwa pohon Rasamala ini memiliki kanopi yang cukup luas dan rimbun dengan jumlah sarang yang cukup banyak. Berdasarkan penghitungan sarang saat penelitian didapat jumlah sarang sebanyak 15 buah sarang. Proporsi jumlah sarang serta bentuk kanopi pohon secara tidak langsung ikut mempengaruhi luas teritori Cangak $\mathrm{Abu} \mathrm{di}$ Lokasi III menjadi terbatas.

Hidup berkoloni selain memiliki keuntungan seperti keamanan yang terjamin dari predator dan deteksi akan bahaya predator lebih cepat, namun juga memiliki beberapa kelemahan. Erlich et al., (1989) mencatat beberapa kelemahan yang ada dari burungburung yang hidup berkoloni, antara lain meningkatnya kompetisi dalam hal pasangan dan makanan, meningkatnya kompetisi kebutuhan akan tempat sarang dan material sarang. Sumber daya (dalam hal ini pohon sebagai tempat lokasi sarang) terbatas, ini menuntut adanya pembagian sarang dalam satu pohon, sehingga dapat ditemui banyak sarang dalam satu pohon. Proporsi jumlah sarang dengan proporsi pohon yang ada inilah yang kemudian menjadi faktor utama yang mempengaruhi keterbatasan luas teritori Cangak Abu. Leahy (1982) mengatakan bahwa luas teritori ditentukan oleh ukuran dari spesies. sehingga makin besar spesies, makin luas teritorinya, namun pada kenyataannya pendapat ini tidak terbukti dalam penelitian ini.

\section{Kesimpulan}

Dari hasil penelitian dapat diambil kesimpulan:

1. Bentuk perilaku teritori Cangak Abu dikategorikan ke dalam dua tipe perilaku, yaitu perilaku peringatan dengan bentuk perilaku vokalisasi dan patrolling flight dan perilaku pengusiran ditandai dengan visual display dan berkelahi (fighting).

2. Luas teritori Cangak Abu di lokasi I sebesar $9 \mathrm{~m}^{2}$, di lokasi II sebesar $6 \mathrm{~m}^{2}$ dan di lokasi III sebesar $9 \mathrm{~m}^{2}$.

\section{Daftar Pustaka}

Bibby, C.J., Bergess, N.D. and Hill, D.A. 1992. Bird Cencus Techniques. Academic Press. Harcount Brace Javanovich, Publisher. London.

Ehrlich, P.R., Dobkin, D.S. and Wheye, D. 1989. Territoriality and Coloniality. www. stanford.edu.ac.

Leahy, C. 1982. The Birdwatcher's Companion : An Encyclopedic Handbook of North American Birdlife. McGraw-Hill Ryerson Ltd., Toronto.

Shannaz, J., Jepson, P. dan Rudianto. 1995. Burungburung Terancam Punah di Indonesia. PHPA dan Birdlife International Indonesia Programme. Bogor.

Widati, L.W. 2000. Studi Habitat Burung Cangak Abu (Ardea cinerea Linn.) di Yogyakarta. Skripsi S1. Tidak Dipublikasikan. Fakultas Biologi Universitas Atma Jaya Yogyakarta. Yogyakarta. 